\title{
Tax Culture Strategies to Avoid Tax Evasion in Mexico
}

\author{
Claudia Irene Nieto Román ${ }^{1}$, Dra. Josefina Morgan Beltrán ${ }^{2 *}$ \\ ${ }^{I}$ Degree in Law from the Autonomous University of Querétaro, student of the Master in Taxes at the Faculty of \\ Accounting and Administration of the $U A Q$, Mexico \\ ${ }^{2}$ Doctor of Administration and research professor at the Autonomous University of Querétaro, MEXICO. \\ Belonging to SIN 1, ORC ID: 0000-0002-6338-6209
}

*Corresponding Authors: Dra. Josefina Morgan Beltrán, Doctor of Administration and research professor at the Autonomous University of Querétaro, MEXICO. Belonging to SIN 1, ORC ID: 00000002-6338-6209

\begin{abstract}
The Political Constitution of the United Mexican States is in charge of regulating the Mexican Tax System; mentioning that it is the obligation of Mexicans; contribute to public expenses, both for the Federation, as well as for the States, Mexico City and the Municipality in which they reside, in the proportional and equitable manner provided by law. From the foregoing, the principles of proportionality and equity arise, which must be faithfully complied with and not fall into avoidance / evasion. This research presents some possible strategies for the implementation of a fiscal culture from basic education that would allow avoiding tax evasion in Mexico; Among the alternatives are the teaching of the subject of tax culture in the basic education of students and this can be implemented through information technologies or free books with simple and easy-to-understand information, the idea is that they know what they are, what is the origin, importance and destination of taxes, among others to create tax awareness.
\end{abstract}

\section{INTRODUCTION}

Since man as a social being began to form communities, he discovered that for the common good it was necessary the existence of a political power that would be in charge of managing the efforts and giving order to the activities that affect all citizens, which are are reflected in education, security, health, infrastructure, etc. for the community.

For this reason, the tax culture is important since citizens must be aware of the payment of contributions established by law, although there are citizens who do not comply despite the obligation, there may be disagreement between those who comply and as a consequence evasion on their part.

It is also important that there is a good tax administration on the part of the State, since the diversion of resources by officials brings nonconformities of the taxpayers, generating distrust of the destination of the contributions and a possible avoidance and evasion of these, which results in the impact on the economic cycle of the country.

In accordance with the above, it is necessary that there is a responsibility of both the taxpayers and the State, the former fulfilling their obligation to pay the contribution and the latter applying it for public spending. The great challenge is that these are equitable and that their destiny is transparent for the society that is the one who contributes those resources.

Many years have passed for the government today to have fiscal laws that allow it to have resources with which to build public works and provide services to society.

\section{THEORETICAL FRAMEWORK}

\subsection{Income and Taxes}

\subsubsection{Income}

The income policy in Mexico is located as a set of guidelines, orientations, criteria and guidelines that the State defines with the purpose of obtaining the necessary resources to pay for its activity. Income can be divided into tax and non-tax income. 
Tax Revenues are those obtained from tax collection, that is, those that do not present a consideration and are established with characteristics of coercion and imposition (Zanatta, 2014).

Non-Tax Income are those that the Federal Government obtains as consideration for a public service, such as rights; for the use of public or private domain assets (products), as well as the application of fines, surcharges and other income indicated in the LIF and which are called exploitation (Zanatta, 2014)).

\subsubsection{History of Taxes in Mexico}

The first manifestation of taxation in Mexico appears in the Aztec Codex, with King Azcapotzalco asking them for tribute in exchange for benefits in his community, leaving the beginning of the tribute records called Tequiamal. The first collectors were called Calpixqueh and were identified by carrying a stick in one hand and a fan in the other. There were several types of tributes that were given according to the occasion, there were war, time religious, etc. The subjugated peoples had to pay two types of tributes, which were in kind or merchandise and tributes in special services.

Hernán Cortés adopted the tributary system of the Aztec people, modifying the form of collection by changing the tributes of flowers and animals for stones and jewels. Cortés' first step was to draw up a list of fiscal documents, he appoints a minister, a treasurer and several accountants in charge of the collection and custody of the Fifth Real. In 1573 the Alcabala was introduced, which is equivalent to VAT, then the right-of-way toll, creating a fiscal legal system called Diezmominero in which the indigenous people paid with work in mines, and the exploitation of the mines was for the State.

As of 1810, the tax system is complemented by the tariff for the government of maritime customs, these being the first import tariffs published in Mexico.

The fiscal weakness of the federal government of Antonio López de Santa Anna establishes the collection of the tribute of one Real for each door, four cents for each window, two pesos for each robust horse, one peso for skinny horses and one peso for each dog. He creates joint responsibility in public finances between the Federation and the State, establishing that part of the proceeds would remain in the hands of the State and a part would be integrated into the Federation's income.

With the arrival of Porfirio Díaz to power, a process of strengthening and centralization of power was carried out in the hands of the Federal Government. In that period, taxes of 30 million pesos were collected, but 44 million pesos were spent generating external debt.

The war caused Mexicans not to pay taxes. After this there was the need to reorganize the administration and resume public finances applying reforms and actions to boost tax activities.

In 1917 and 1935 various taxes were introduced, such as services for the use of the railroad, special taxes on the export of oil and derivatives, for consumption of electricity, telephone, bells, closed bottles, notices and advertisements. At the same time, the income tax and the gasoline consumption tax are increased. However, such measures caused social benefits, with the introduction of services such as civil services, retirement due to old age with a pension and in general. Increasing taxes on items that are harmful to health and taxing luxury items.

\subsubsection{Concept}

According to the Fiscal Code of the Federation in its article 2, section I, it says that taxes are the contributions established by law that must be paid by natural and legal persons who are in the legal or factual situation provided for by the same and that are different from social security contributions, enhancement contributions and entitlements.

The definition of taxes or tax contribution contains several elements, and therefore there may be different definitions about it. Among the main definitions mentioned by are the following:

Eherberg's theory: "Taxes are benefits in money, to the State and other entities of Public Law, which they claim by virtue of their coercive power, in a form and amount determined unilaterally and without special consideration in order to satisfy collective needs"

Vitti de Marco: "The tax is a part of the citizen's income, which the State receives in order to provide itself with the necessary means for the production of general public services"

Luigi Cossa: "The tax is a proportional part of the wealth of individuals deducted by the public authority, in order to provide that part of the general utility expenses that are not covered by the patrimonial income" 
José Alvarez de Cienfuegos: "The tax is a part of the national income that the State appropriates to apply it to the satisfaction of public needs, distracting it from the aliquots of that income owned by private economies and without offering them specific compensation and reciprocal on your part "

\subsubsection{Elements}

The most important elements of the tax are: subject, object, base, quota and rate.

a) Subject. This can be of two types: active and passive. The active subject is the one who has the right to demand the payment of taxes. Thus in Mexico the active subjects are: the Federation, the states and the municipalities. The taxable person is any natural or legal person who has the obligation to pay taxes in the terms established by law. However, it is necessary to note a difference between the taxpayer and the taxpayer, since confusion is often generated, as is the case for example with indirect taxes. The taxpayer is the one who has the legal obligation to pay the tax, while the taxpayer is the one who actually pays the tax.

b) Purpose. It is the activity or thing that the Law indicates as the reason for the tax, in such a way that it is considered as the event that generates the tax.

c) Base. It is the taxable amount on which the amount of the tax is determined.

d) Fee. It is the amount of money that is received per tax unit, in such a way that it is set in absolute amounts.

e) Rate. It is the amount of money that is perceived as a percentage per unit.

In Mexico, the taxes that generate the most income to the federation are mainly income tax, VAT, and IEPS.

The ISR (Income Tax) It is one of the federal taxes classified as one of the most important that affects the pocket of Mexicans by directly taxing the income of individuals and companies. The purpose of the Income Tax in Mexico is to obtain income for any of the following causes: disposal of goods, subordinate services, interests, prizes, dividends and profits, professional activities, leasing.

VAT (Value Added Tax) is an indirect or consumption tax, it is a contributory regime on added value in all stages of production, marketing and final sale to the consumer. In Mexico, it is applied on a broad tax base (except food products and housing, among other sensitive items) at a uniform rate. There is a zero rate on exports and in some technical sectors.

The IEPS (Special Tax on Production and Services) is applied at an ad valorem rate, such as a specific production quota, or both. In an ad valorem rate, the effect of the tax should be equivalent to taxing all stages of production and marketing, avoiding their accumulation, even if it is only applied at a given time (Figure 1)

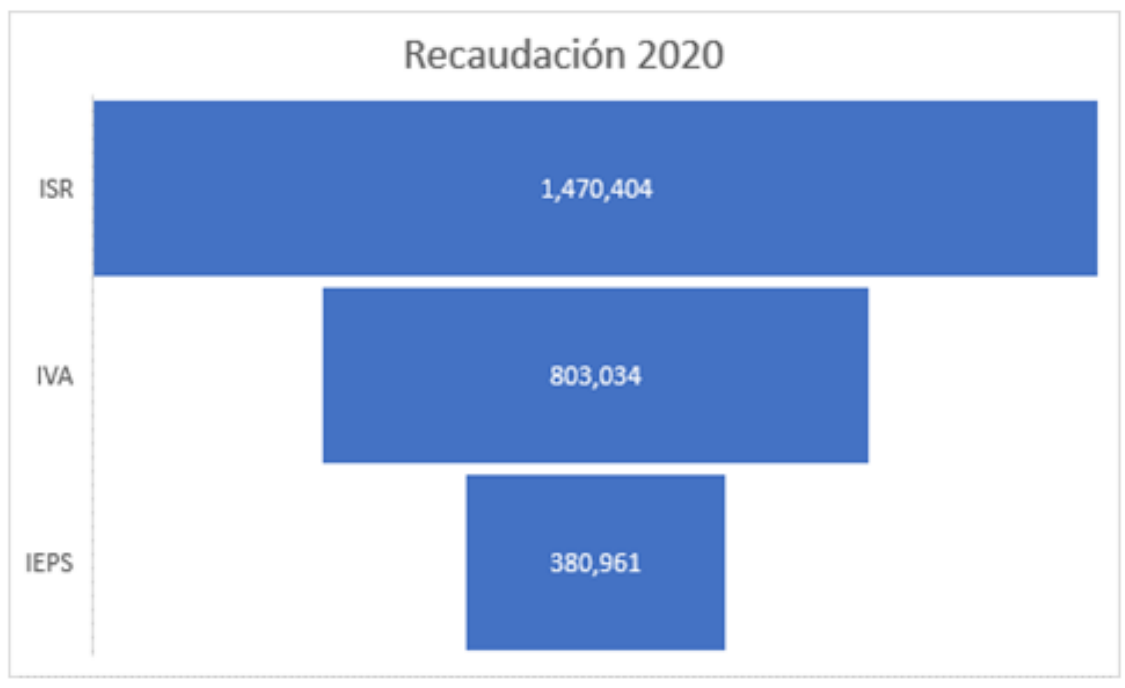

Figure1. Income tax, VAT and IEPS collection amounts for 2020

* The above amounts in millions of pesos

Source: SAT (2020) 
According to the above, it can be seen that until October 2020 it was possible to collect income tax first, second, value added tax and third was Special Production and Services Tax, clarifying that it is also collected from other taxes such as Business Flat Rate Tax, Tax on Cash Deposits, Tax on Ownership or Use of Vehicles (ISTUV).

However, the expected amounts were not achieved, according to the Income Law of the Federation for fiscal year 2020, it was intended to obtain the following (in thousands)

ISR $=1,852 ' 852.30$

VAT $=1,007 ' 546.00$

IEPS $=515^{\prime} 733$

\subsubsection{Tax Culture}

Culture is called the knowledge and values that by upbringing allow the individual to develop and establish their critical judgment, a way of life, customs, morals and new knowledge, as well as promoting belonging to a particular people.

Tax culture is understood to be the knowledge and values that allow to develop and establish a critical judgment and develop values on public finances, as well as the way of compliance or non-compliance and reaction to tax aspects.

The SAT (Tax Administration Service) has been implementing a tax transformation plan, its objective is to generate a tax culture through educational and training actions in values, with the citizen being the axis to promote voluntary compliance.

Ideally, future generations grow up with a fiscal civic spirit that generates the responsibility to contribute, have an education that makes us reflect and understand from a very young age what contributions are, with grounded values, which will generate a culture so that when we have That contributing to the Federation, State or Municipality is recognized as beneficial to all, as well as in the event of occupying a public position, knowing how to handle the resource responsibly and ethically for the betterment of our society.

The payment of taxes can be carried out by the will of the taxpayers or application of force. The force is established by the State in the laws and that they are mandatory, while the will can only be given by a Fiscal Culture based on a solid foundation, established from basic education, it is required that the population obtain knowledge about the topic from an early education and understand the importance of your tax responsibilities.

It is a bilateral commitment between taxpayers and the State, the former complying with the tax obligation and the State committing that the resources obtained by paying taxes are applied and distributed to the same society in an assertive way, since the inadequate Distribution leads to discontent on the part of taxpayers, therefore, in addition to the need to include tax culture at the basic levels, it is also important to know issues related to the duty that Mexicans have to contribute and the duty to serve. with the state, so that it can comply with its constitutional obligation to ensure the common good and to provide services, all of this generating through the implementation and monitoring of a Tax Culture.

\subsection{Tax Avoidance and Evasion}

Failure to comply with the obligations to contribute to the public spending of the Federation, States or Municipalities, implies several concepts among them; tax avoidance, evasion or fraud. These concepts deal with strategies that seek to reduce the amount of taxes to be paid, it is not only an affectation for the Federation, it is also for taxpayers and citizens.

Avoidance is a conduct that is carried out in order to totally or partially avoid the tax burden of economic activities carried out by taxpayers. Diep (2001) mentions that avoidance is understood to be the action of avoiding influencing a certain tax regime, when there is the possibility of adopting a different one, while evasion is the fact of being a taxpayer in some way determined by law, and not complying with the obligations in this regard, evasion occurs when the subject, being a taxpayer of a certain tax, and having carried out operations that imply the causation and payment of said tax, refrains from complying, this is in violation of the law Since the obligation exists, it has been given and the subject does not comply with it. 
Rosembuj (2019), understands by tax avoidance; avoid the application of the tax rule to obtain a patrimonial advantage on the part of the taxpayer that would not be realized if facts and legal acts or contractual procedures were not put into practice on their part with the dominant purpose of avoiding it, while for him evasion says that the core of the transgressive conduct is none other than the concealment of income, assets and rights of economic content through the use of materially or ideologically false documents, the performance of acts or legal businesses.

It is essential to differentiate the avoidance, which is the non-verification of the taxable event and therefore the non-existence of the tax, from the evasion, which consists in verifying the performance of the event that generates the tax obligation, such as non-compliance with the corresponding payment, as well as delaying the moment in which it becomes enforceable, through illegal actions or omissions, so that they generally postpone the occurrence of the taxable event. Tax evasion is any and all way to exempt yourself from taxation. In the strict sense, it means deriving from the voluntary and willful, omisive or commissive conduct, of the taxpayers exempting themselves from compliance, in whole or in part, of the tax obligations.

The Tax Code of the Federation of Mexican legislation, regulates tax evasion, classifying it as a crime of tax fraud. The distinction between tax evasion and fraud, Arrioja Vizcaino (2020), argues that evasion operates fundamentally as a case of omission, that is, the taxpayer passively stops covering taxes, either due to ignorance or material impossibility, the Tax fraud is characterized by the actions of the taxpayer, who carries out a series of machinations, tricks and fallacies, with the deliberate purpose of avoiding tax obligations, it is a case of bad faith, in which it is intended to cause a damage to the Federation through deception.

In accordance with article 108 of the Federal Tax Code, the crime of tax fraud is committed by whoever, with the use of deceit or taking advantage of errors, totally or partially omits the payment of any tax or obtains an undue benefit to the detriment of the federal treasury. . The total or partial omission of any contribution referred to in the preceding paragraph includes, interchangeably, the provisional or definitive payments or the tax for the year under the terms of the tax provisions. The crime of tax fraud and the crime provided for in Article 400 Bis of the Federal Criminal Code, may be prosecuted simultaneously. The crime of tax fraud is presumed to have been committed when there is income or resources that come from operations with resources of illicit origin.

\section{Methodology}

The objective of this research is to generate information on the knowledge that exists about a Tax Culture to understand the importance of paying taxes and why many of the taxpayers prefer to evade than to pay.

Interviews were conducted with professionals in the tax area, the business public and the general public in which they were questioned from the meaning of taxes, as well as their knowledge of the application of the same and trying to identify the degree of trust and security that is has in the tax authorities.

The results were able to identify weak aspects, as well as suggestions from experts on the subject to improve compliance.

In Mexico, the main source of financing is taxes, tax collection is the lowest measured as a percentage of GDP among the member countries of the OECD (Organization for Economic Cooperation and Development). The current situation of Mexican public finances is precarious, since there is limited fiscal space for the implementation of public policies.

\section{RESULTS AND CONCLUSION}

Taxes are one of the most important instruments that the State has to promote economic development, especially because through these it is possible to influence the levels of income allocation among the population, either through a certain level of income. taxation between the different strata or, through social spending, which largely depends on the level of collection achieved.

The main causes for which the payment of contributions is evaded according to the interviewees are the following:

- Lack of Tax Culture

- Incorrect administration by the State 
- Lack of guidance for the fulfillment of obligations

- Complexity of the laws

- Lack of fluency

The strategies proposed in this research are:

$>$ the implementation of a fiscal culture from basic education, this would generate an awareness in children of the importance of contributing to the fulfillment of obligations, they learn from an early age about what their obligations and rights are, it is not about generating them a concern at an early age, but they do have the knowledge that for the common good of a society everyone must contribute, encourage them of the commitment they will have with society so that they do so out of conviction and not out of obligation. It can be implemented through information technologies or free books with simple and easy-to-understand information, the idea is that they know what they are, what is the origin, importance and destination of taxes, etc.

$>$ Implementation of a system where informal businesses can be detected, it is understood that some taxpayers opt for this modality due to all the regulations that taxation implies in the formal system, but if an effective program is implemented where there are real benefits, it would help development and economic growth of the country, including a decrease in rates, as long as all taxpayers comply with their obligations as it would imply a higher income.

$>$ Constant information from the collection agencies, promote and publicize more the actions and use that the Tax Administration Service has to help taxpayers, so that they come with more security to carry out any procedure related to their business,

$>$ Implement a system where the collection is more rigid, that there is supervision of both large and small companies to combat evasion and avoidance and not allow benefits or forgiveness except in special cases due to the nature of the business or circumstances of force majeure.

Figure 2 shows the outline of the investigation contemplating the current situation from the perspective and dimensions of analysis of Tax Culture, Tax Collection and Evasion.

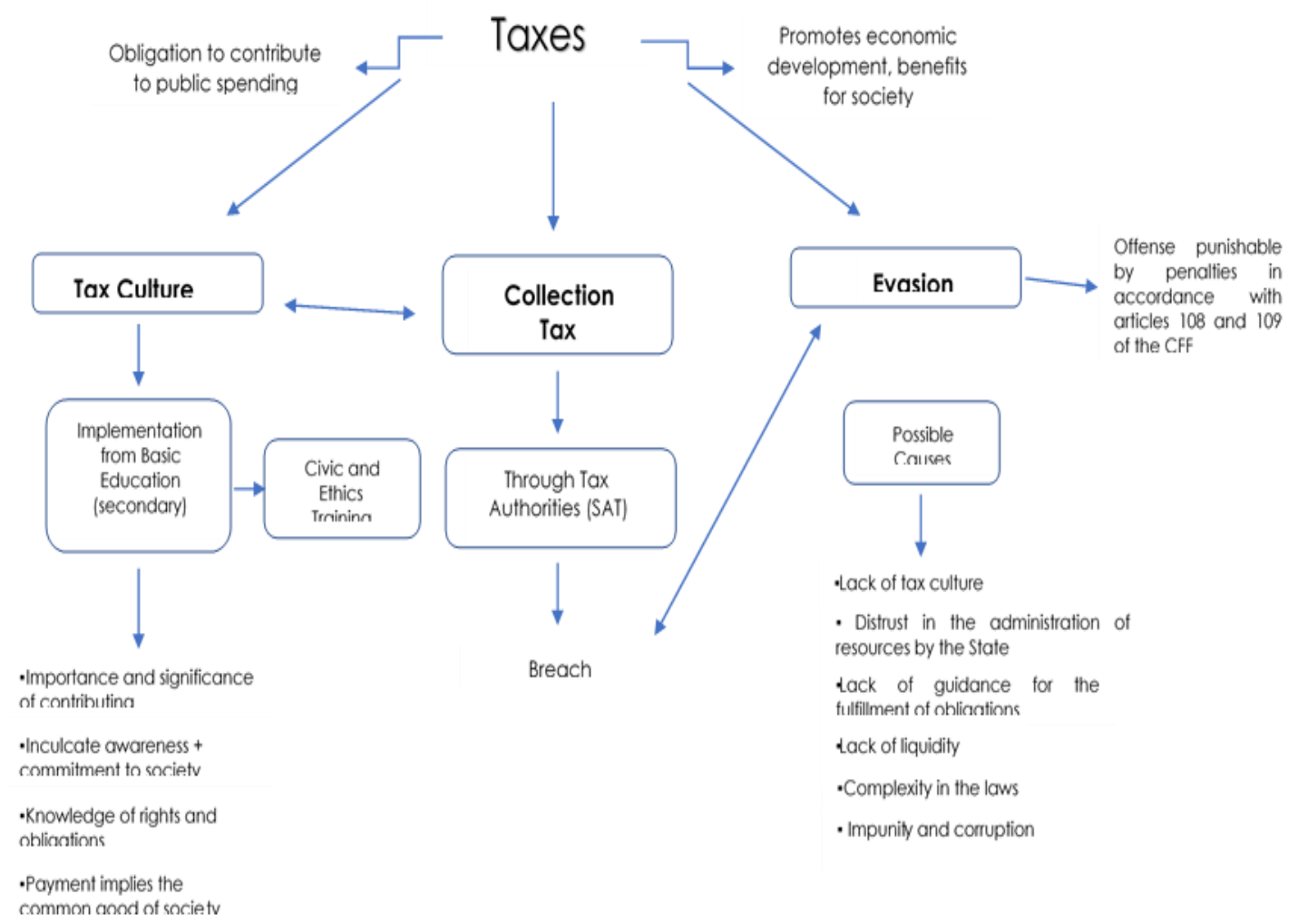

Figure2. Model of the tax situation in Mexico

Source: self made 


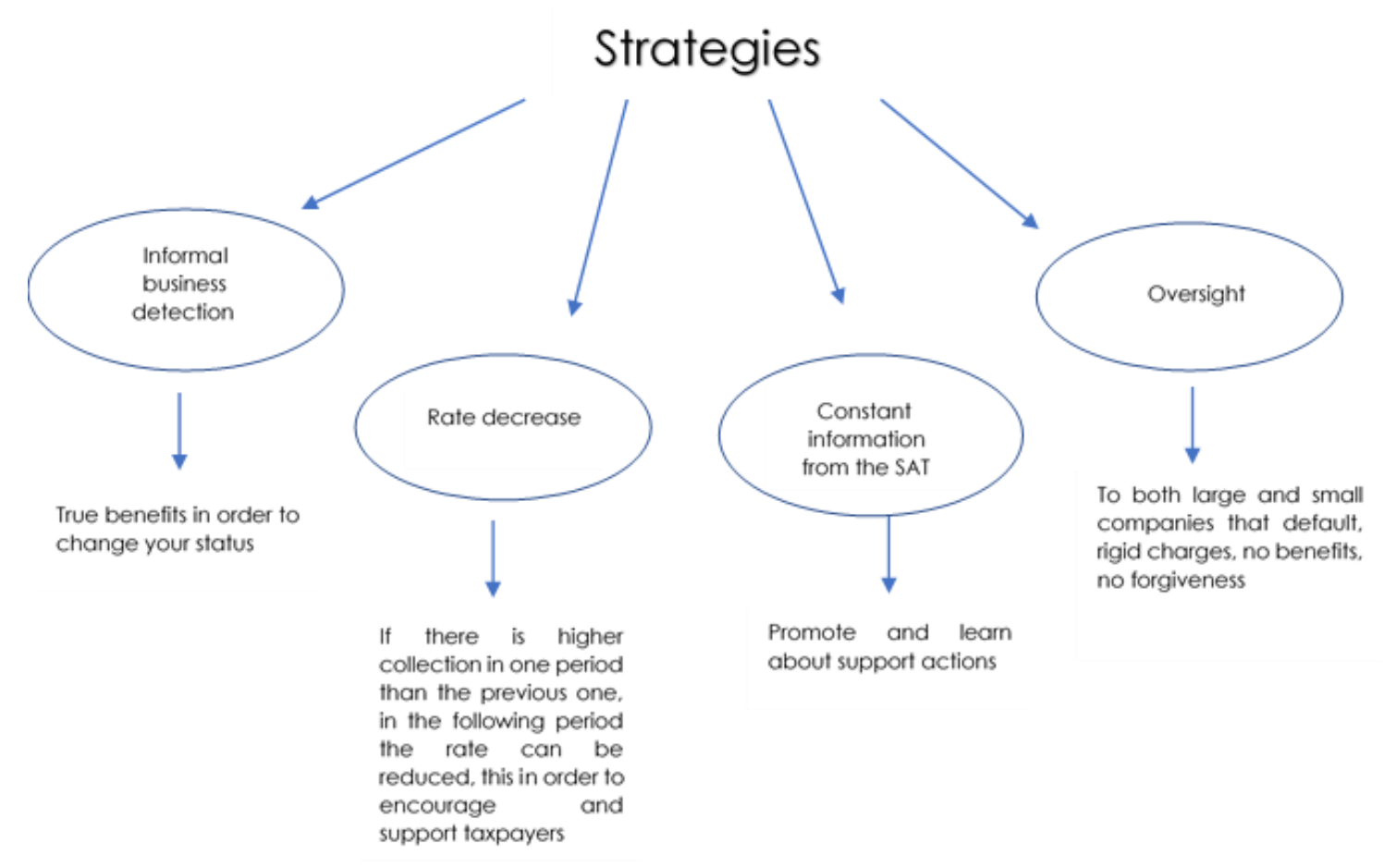

Figure3. Model of strategies to avoid tax evasion

According to the research carried out on non-compliance with tax obligations in Mexico, the causes of them are identified and some strategies are proposed that can support the search for alternatives that strengthen the tax system in the country and that together With other investigations, ideas are provided in terms of fiscal improvement and in general the common good and well-being of Mexicans

\section{REFERENCIES}

[1] Arrioja V. A. (2020). Tax Law. Mexico. Ed. Themis

[2] Superior Audit of the Federation. (2020). Conference given by Dr. Héctor Juan Villarreal Páez, on January 18, 2016 at the facilities of the Superior Auditor of the Federation. Didactic notes. Retrieved December 17, 2020 from: https://www.asf.gob.mx/uploads/61_Publicaciones_tecnicas/2._Introduccion_al_Sistema_ Fiscal_Mexicano.pdf

[3] Bonilla L. I. (2002). Mexican tax system 1990-2000 policies necessary to achieve equity: the tax reform of the present administration. Bachelor's thesis in economics. Autonomous University of Mexico.

[4] Bonilla, L. UNAM, THESIS (2020). UNAM Faculty of Economics, consulted on January 10 from: http://www.economia.unam.mx/secss/docs/tesisfe/BonillaLI/cap1.pdf

[5] Bonilla, L. UNAM, THESIS (2020). UNAM Faculty of Economics, consulted on January 10 from: http://www.economia.unam.mx/secss/docs/tesisfe/BonillaLI/cap2.pdf

[6] Bonilla, L. UNAM, THESIS (2020). UNAM Faculty of Economics, consulted on January 10 from: http://www.economia.unam.mx/secss/docs/tesisfe/BonillaLI/cap3.pdf

[7] Bonilla, L. UNAM, THESIS (2020). UNAM Faculty of Economics, consulted on January 10 from: http://www.economia.unam.mx/secss/docs/tesisfe/BonillaLI/cap4.pdf

[8] Cere Consultores Fiscales (2019). The History of Taxes in Mexico. (May 19, 2019) accessed on December 10, 2020 from: https://cereconsultores.com.mx/blog/37-historia-impuestos-mexico

[9] Political Constitution of the United Mexican States, Article 31 F. IV (2020)

[10] Tax Law (2014). Importance of taxes. Consulted on December 15, 2020 from: https://derechofiscalunivia.wordpress.com/2014/09/09/importancia-de-los-impuestos/

[11] Diep Diep Daniel (2001) Tax planning today. Editorial Pac, Mexico.

[12] The taxpayer (2020) consulted on November 12, 2020 from: https: //www.google.com/search? $\mathrm{Q}=$ evasion $+\mathrm{y}+$ elusion + fiscal \& rlz $=$ 1C1GCEA_enMX901MX901 \& oq $=\&$ aqs $=$ chrome.0.69i59i45018.693064668j0j15 \& sourceid $=$ chrome $\&$ ie $=$ chrome $\&$ ie -8

[13] Flores Z. E. (2016) Elements of Mexican Public Finance, Ed. México D.F. original article 1946, p. 33. Journal of the National School of Jurisprudence-virtual legal library. Retrieved December 20, 2020 from: https://revistas-colaboracion.juridicas.unam.mx/index.php/escuela-naljurisprudencia/article/view/20780/18671 
[14] García G. A. (2019). Collection comparison. Main taxes. Centro de Investigación Económica y Presupuestaria, AC consulted on October 13, 2020 from: https: //ciep.mx/comparativo-de-recaudacionprincipales-impuestos/\#: : : text $=\mathrm{El} \%$ 20pa\% C3\% ADs\% 20que \% 20m\% C3\% A1s\% 20 collects, it is $\%$ 20of\% 201.9\% 25\% 20of\% 20GDP.

[15] Government of Mexico (2019). The 6 collection measures that you should know about the Economic Package 2020 (09-10-2019) consulted on October 10, 2020 from: https://www.scmasociados.com/las-6medidas-recaudatorias-que-debes-saber- of-the-economic-package-2020 /

[16] Taxes (March 19, 2012). Definition of taxes. Retrieved December 11, 2020 from: https://impuestosimpuestos.blogspot.com/2012/03/definicion-de-impuestos.html

[17] NON-TAX INCOME AND FEDERALISM: ALLOCATION FOR THE MULTIPLE CONTRIBUTION FUND- María Susana Sarur Zanatta * 29- Administrative Science, No. 1 Year 2014- JEL Classification: H27-pag. 86-99

[18] Federation income law (2020), consulted on 01-12-2021 from: http://www.diputados.gob.mx/LeyesBiblio/ abro/lif_2020/LIF_2020_abro.pdf

[19] Legal Framework of the Organization (2020). José Angel Cu Tinoco. What are taxes. Retrieved February 8, 2021 from: https://marcolegaldelaorganizacion.blogspot.com/2017/01/unidad-4-apunte-que-son-losimpuestos.html

[20] Treasury number (2020). Federal Government Income. Retrieved November 18, 2020, from: https://www.mexicoevalua.org/numerosdeerario/portfolio/ingresos-por-isr/

[21] Rosembuj, T. (2019). Taxation and capitalism of surveillance. Rivista di diritto finanziario e scienza delle finanze. ISSN 0035-6131, No. 2, 2019, pp. 134-176

[22] Prodecom (2020). Consumer Attorney's Office. What every taxpayer should know. Consulted on December 18, 2020, from the page: http://www.prodecon.gob.mx/Documentos/Cultura\%20Contributiva/ publicaciones/sistema-impuestos-M\%C3\%A9xico/files/downloads/folleto_final_01-04-15 [4].pdf

[23] Secretary of Finance and Public Credit (2021). SAT open data consulted on February 20, 2021 from: http://omawww.sat.gob.mx/cifras_sat/Paginas/datos/vinculo.html?page=IngresosTributarios.html

[24] Eherberg theory (2011). Taxes. Comments, opinions and our points of view on the matter of taxes. Retrieved February 10, 2021 from https://impuestosudec.blogspot.com/2011/03/teoria-de-eheberg.html

[25] Vitti de Marco (2020), TAXES. DEFINITION VITTI DE MARCO. Retrieved January 15, 2021 from: https://vdocuments.mx/impuestos-definicion-vitti-de-marco-el-impuesto-es-una-parte-de-la-renta.html

\section{AUTHORS' BIOGRAPHY}

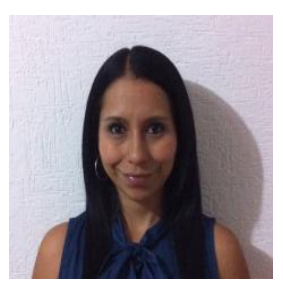

CLAUDIA IRENE NIETO ROMÁN, Master's student in Taxes and Law Degree, both from the Autonomous University of Querétaro. She is an administrative assistant in the Postgraduate Program of the Faculty of Accounting and Administration at the Autonomous University of Querétaro from 2010 to date.

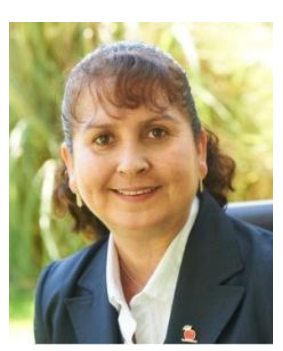

Dr. Josefina Morgan Beltrán, Research Professor of the Autonomous University of Querétaro, head of the postgraduate division of the Faculty of Accounting and Administration, Doctor of Administration with post-doctorate in Education, member of the National System of Researchers level I (SNI), member of the Program for Professional Development Teacher (PRODEP) and the National Association of Accounting and Administration Faculties and Schools (ANFECA).

Citation: Claudia Irene Nieto Román, Dra. Josefina Morgan Beltrán, “Tax Culture Strategies to Avoid Tax Evasion in Mexico" International Journal of Managerial Studies and Research (IJMSR), vol 9, no. 4, 2021, pp. 40-47. doi: https://doi.org/10.20431/2349-0349.0904005.

Copyright: (C) 2021 Authors. This is an open-access article distributed under the terms of the Creative Commons Attribution License, which permits unrestricted use, distribution, and reproduction in any medium, provided the original author and source are credited. 